\title{
A Solution for Increasing the Optimism of Physically Disabled Adolescents
}

\author{
Akhmad Syahputra Syarif \\ Universitas Negeri Makassar \\ Makassar, South Sulawesi, Indonesia
}

\author{
Muh. Ahkam \\ Faculty of Psychology \\ Universitas Negeri Makassar \\ Makassar, South Sulawesi, Indonesia
}

\author{
Ahmad Ridfah \\ Faculty of Psychology \\ Universitas Negeri Makassar \\ Makassar, South Sulawesi, Indonesia \\ ahmad.ridfah@unm.ac.id
}

\begin{abstract}
- this research aims to determine the increase of optimism of physically disabled adolescents after joining "Bina Cita Training" based on SAVI method at Panti Sosial Bina Daksa Wirajaya Makassar. Subjects of this study are 12 physical disabilities adolescents. The characteristic of the subjects is 12-21 years old of physically disabled adolescents who can read and write. This research is quantitative research with the quasiexperimental approach with One-Group Pretest-Posttest Design. The Wilcoxon test shows the very significant difference between the pre-test value and post-test value, it can be seen from 0.001 which is less then 0.01 and improvement score of post-test just then pre-test score, so it can be concluded there is an increase of optimism of physically disabled adolescents in Panti sosial Bina Daksa Wirajaya Makassar after joining Bina Cita training based on SAVI method.
\end{abstract}

Keywords: Adolescents; physically; training

\section{INTRODUCTION}

The data from BPS in 2004 describes that quadriplegic individual always feels and discriminated by society, including society attitude to mock or laugh (69.9\%), the attitude of society that rejects quadriplegic presence $(35.5 \%)$, aloofness $(15 \%)$ and protective attitude of society $(13.7 \%)$. Therefore, it is suitable for the interview that was conducted by the researcher to quadriplegic with initial F in Panti Sosial Bina Daksa Wirajaya Makassar. F reveals that he frequently experiences the anxiety. The anxiety such us is living alone, raising the family, and making proud the family (interview conducted January 20th, 2015). Moreover, the other quadriplegic with initial A often feels interrupted by lack confident and excluded feeling. An also admitted to feeling afraid frequently, one of his fear is about marriage and job. The anxiety and fear that are experienced by $\mathrm{F}$ and $\mathrm{A}$ are a projection of the psychiatric state. The motoric function disruption as the result of disease, accident, or congenital factor will affect the other senses harmony and also affect the psychological abuse function.

Optimism is an important thing that is owned by individual and able to be a good solution to the issues facing by quadriplegic teens. Optimism is proved to affect the physical and psychological that grows the comfort feeling of ours, selfacceptance, and growth. An optimistic individual can be better to adopt the emotional state and also has better health [1]. Optimism also can assist individuals in improving the health psychologically, having a comfortable feeling, doing problemsolving logically. Thus, it can increase the immunity of the body. Besides health, optimism also has a role in social life as optimism filled the important functions in marriage, partnerships, and social relationships [2].

Optimism will give happiness on quadriplegic teens; the perceived happiness will help individuals in supporting all the plans in life because happiness is a social asset that demands lifelong maintenance [3]. Hence, happiness is the key to success which must be well maintained. To keep the quadriplegic teens' happiness, it is needed an educational program that can increase the optimism and also puts individual comfort for more active in learning.

One of the programs that are used in several training and effective is the SAVI method because SAVI method can increase interest in learning [4]. The increasing of attention characterizes it, give priority to learning, delight in learning, and curiosity. SAVI method is the approach which involves the senses of the body that supports learning, learning by moving physically active, taking advantage of the senses as much as possible, and making the whole body, as well as the mind, is involved in the learning process [5]. Therefore, further research is needed to know whether the training based SAVI method can increase the optimism of quadriplegic. See the importance of it; then the researcher-researched with the title "Bina Cita Training based on SAVI method as a solution for increasing the optimism of physically disabled adolescents in Panti social Bina Daksa Wirajaya Makassar."

\section{RESEARCH METHODS}

This research is quantitative research with the quasiexperiment approach. The design of this research used a OneGroup Pretest-Posttest. The technique of sampling in this research is purposive sampling. Purposive sampling is a technique of determining the sample by the criteria determined by the researcher [6]. The characteristics of the subject in this study are aged between 12-21 years, and the subject can read and write. Data retrieval in this research consists of measurements using the scale of optimism, observation sheet, and evaluation research sheet. 
Hypothesis test, the test that used is Wilcoxon. The instrument that is used to describe the inferential statistical analysis in this study is SPSS 20 software.

\section{RESULTS AND DISCUSSION}

The subjects in this research are residents of Panti Asuhan Tunadaksa Wirajaya Makassar total 12 people. Age reviews the subject of research, gender, and education. The age of the subjects is for 17 years there are three persons 18 years there are four people, 19 years there are two people, 20 years there is one, and 21 years there are two people. Male subject there is three people and female there are nine people. The education of the subject is no school there are two people, elementary there are five persons, junior there are two persons and senior high school there are three people.

The hypothesis in this research stated that there was increased optimism of quadriplegic teens after following Bina Cita training based on SAVI method. Hypothesis test in this study is using Wilcoxon analysis techniques with the criteria of value if the value of $p<0.05$. The output shows that the value of the significance of Wilcoxon signed ranks test is 0.002. The hypothesis in this study there was increased optimism of quadriplegic teens after following Bina Cita training based on SAVI it means that is used for the analysis was one-tailed, so 0.002 divided two so the value of their significance is 0.001 . It shows that the value of significance, where $p=0.001$, then $0.05 \mathrm{Ha}<$ accepted and Ho is rejected. Wilcoxon test results showed that there was increased optimism of quadriplegic teens after following Bina Cita training based on SAVI. The increased optimism may also be seen in the comparison of the empirical average. The empirical average optimism pre-test is at 62 while the empirical average optimism post-test is at 67.08 , there is a difference between 5.08, it shows that there is an increase in optimism after training community development goals.

A person's level of optimism is the best indicator for determining achievement rather than scholastic tests. The high optimism tends to encourage individuals to achieve the highest standards. Optimism will make a child do not easily give up before trying hard, despite the difficult challenges facing individuals. Individuals who face problems be sure himself able to solve these challenges successfully. Quadriplegic teens will face two problems, the first is the issue of a quadriplegic and the second is the issue of teenage problems. Bad events come unexpectedly, and insistent tends to make someone powerless to face it. Mental strength fights it that is optimism [7].

The material provided on the training based SAVI method is a result of the analysis of the needs of the subject and the literature review researchers do. The entire training material based on the method of SAVI so that one material provided by four different methods, those are somatic, auditory, visual and intellectual. The purpose of these materials namely, helping participants to develop and recognize the concept of optimism, optimistic thinking theory comprehends models A-B-C-D-E Seligman, knowing the effective steps to think optimistic and able to benefit from effective measures to think optimistic. Any such material derived from a general Instructional Objectives that participants have the skills of self-control to think optimism.

Methods used in learning effective SAVI due to physical motion, SAVI combines intellectual activities by using the entire senses, so that gives a great effect in learning. The good learner should emulate the learning style of small children, small children's learning ability is very good is not sitting all the time to learn but by moving the body and whenever we can use the whole sensory [5].

SAVI method related to the concept of activity-based learning. Activity-based learning, opposed the contemporary learning style tends to be stiff and makes the physical body learners inactive for a long time. In the concept of activitybased learning, to enable the maximum individual thinking ability, that individual must move the body and activates the entire senses, to strengthen the mental processes and the mental process is to think. From these same things, SAVI is far more effective than presentation method, the task method and learning media method [5].

The training provided is expected to help quadriplegic teens for dealing with the problems they faced, either because the problem of physics disability or problem of the teens, with the ability to apply optimism, was studied at the time of training. Responses to training subject matter varied, but the overall positive for the improvement of future training as revealed one of the subjects of evaluation training in sheet column impression towards training. The subject recognizes the training gives a new knowledge so that it can guide the subject to be optimistic. Other subject recognizes community development goals very good training in the application and can bring the subject up to the motivation to think optimistic. It is related to the observations conducted by the observer noted the circumstances at the time of training namely the trainer could act properly by creating a conducive atmosphere and can provide motivation to participants. While the subject advice about training, so that in future community development training goals instead of just estimated on the two days only, but are long-term so the subject regarding the ability to think optimistic can be follow-up well.

\section{CONCLUSION}

Based on the results of research conducted can be concluded that "Bina Cita Training" based on SAVI method can increase the optimism of physically disabled adolescents in Panti social Bina Daksa Wirajaya Makassar. The evaluation of the implementation of training, in General, is a category is appropriate or satisfactory in raising optimism.

\section{REFERENCES}

[1] L. M. Warner, R. Schwarzer, B. Schüz, S. Wurm, and C. Tesch-Römer, "Health-specific optimism mediated between objective and perceived physical functioning in older adults," J. Behav. Med., vol. 35, no. 4, pp. 400-406, 2012.

[2] O. Bennett, "Cultures of optimism," Cult. Sociol., p. $1749975511401270,2011$. 
[3] R. Schoch, The secrets of happiness: Three thousand years of searching for the good life. Simon and Schuster, 2006.

[4] D. Iskandar, A. R. Hamdani, and T. Suhartini, "Implementation of Model Savi (Somatic, Auditory, Visualization, Intellectual) To Increase Critical Thinking Ability in Class IV of Social Science Learning on Social Issues in the Local Environment," JETL (Journal Educ. Teach. Learn., vol. 1, no. 1, pp. 45-50, 2016.

[5] D. Meier, The accelerated learning handbook: A creative guide to designing and delivering faster, more effective training programs. McGraw Hill Professional, 2000.

[6] A. J. Pickard, Research methods in information. Facet publishing, 2013.

[7] J. Ren, N. Peng, and J. Luo, "Optimistic Intelligence Quotient: Playing A More Important Role in Human Development than IQ and EQ [J]," Adv. Psychol. Sci., vol. 4, p. 2, 2013. 